\title{
Pivotal Role of Both TNF- $\alpha$ 238G/A and TCF7L2 C/T Gene Polymorphisms in Type 2 Diabetes
}

\author{
Sahar H. El Hini ${ }^{1}$, Amira Taha Zaki Ahmed ${ }^{2 *}$, Eglal MS. Hamed ${ }^{2}$, Yehia Z. Mahmoud ${ }^{2}$, Amel Mahmoud Kamal Eldin ${ }^{3}$, \\ Hend M. Abdelghany ${ }^{4}$ \\ ${ }^{1}$ Diabetes and Endocrinology Unit, Minia School of Medicine, Minia University, Minya, Egypt; ${ }^{2}$ Department of Internal Medicine, \\ Minia School of Medicine, Minia University, Minya, Egypt; ${ }^{3}$ Department of Clinical Pathology, Minia School of Medicine, Minia \\ University, Minya, Egypt; ${ }^{4}$ Department of Biochemistry, Minia School of Medicine, Minia University, Minya, Egypt
}

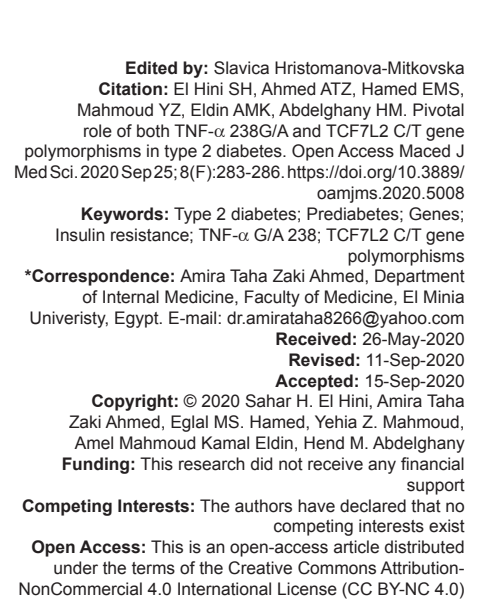

\section{Abstract}

Single nucleotide polymorphism (SNP) studies in the promoter region of tumor necrosis factor-alpha (TNF- $\alpha$ (238)) have suggested its role in increased insulin resistance and also in the progression from prediabetes to type 2 diabetes (T2DM). It has been reported that genetic variations in the promoter region regulate TNF- $\alpha$ production and transcription, and they influence susceptibility to inflammatory-related diseases. Impairment of normal functioning of the $\beta$-cells of pancreatic islets is one of the main causative factors for the suppression of insulin secretion. TNF- $\alpha$ is among the main stimuli that induce the inflammation in pancreatic islets which lead to the induction of apoptosis in $\beta$-cells of pancreatic islets. Transcription factor 7-like 2 (TCF7L2) gene has been found to be one of the most risky genes for prediabetes and progression toT2DM. However, the underlying mechanism of this is still unknown. This is a review article demonstrating the possible mechanisms of both TNF- $\alpha$ G/A 238 and TCF7L2 C/T gene polymorphisms in prediabetes and type 2 diabetes mellitus.

\section{Introduction}

TNF- $\alpha$, along with other pro-inflammatory cytokines, plays a central role in the pathogenesis and development of obesity-induced insulin resistance as evidenced by the augmented levels of TNF- $\alpha$ in systemic circulation, liver, and adipocytes [1], [2], [3], [4]. The phenomenon of TNF- $\alpha$-induced insulin resistance is dependent on the intracellular and molecular mechanisms that involve the activation of stress-related protein kinases such as inhibitor kappa-beta kinase beta $(\mathrm{IKK} \beta)$, Jun $\mathrm{N}$-terminal kinase (JNK), and nuclear factor kappa-beta (NF-KB pathway) [5].

\section{Insulin Resistance in Adipose Tissues}

In diabetic individuals, the level of messenger ribonucleic acid (mRNA) of TNF- $\alpha$ and its protein increases in adipose tissues. Another way by which
TNF- $\alpha$ impairs insulin sensitivity in adipose tissues consists of downregulation of protein level of insulin receptor substrate1 (IRS-1) and glucose transporter 4 (GLUT4). TNF- $\alpha$ also decreases fatty acid oxidation and increases plasma free fatty acid levels [6]. TNF- $\alpha$ alters lipid metabolism and protein in adipose tissues [7]. In isolated adipocyte, TNF- $\alpha$ suppresses the action of genes that are responsible for regulating the level of fatty acids uptake within the tissues. TNF- $\alpha$ is also responsible for the inhibition of lipoprotein lipase and starts lipolysis in adipose cells. As a result of this lipolysis, non-esterified fatty acid level increases, which results in the development of insulin resistance [8].

\section{Insulin Resistance in Peripheral Tissues}

TNF- $\alpha$ produced by the muscles also induces insulin resistance in skeletal muscles by inhibiting insulin action in peripheral tissues. Mostly, the muscles are accounted for glucose disposal, and it has been 
reported that TNF- $\alpha$ increases the phosphorylation of JNK, and IRS-1 which is linked with the cascade of insulin signaling impairment in peripheral tissues [9].

\section{TNF- $\alpha$ and Dysfunctioning of $\beta$-Cells of Pancreatic Islets}

Impairment of normal functioning of the $\beta$-cells of pancreatic islets is one of the main causative factors for the suppression of insulin secretion. TNF- $\alpha$ is among the main stimuli that induce the inflammation in pancreatic islets which lead to the induction of apoptosis in $\beta$-cells of pancreatic islets [10], [11], [12]. TNF- $\alpha$ does this job by activating the transcriptional factor, that is, $\mathrm{NF}-\kappa \mathrm{B}$ which is an important modulator of pancreatic cell death [13], [14], [15].

\section{Role of TCF7L2 Gene Polymorphism in T2DM}

\section{Genetic mutation in TCF7L2}

A previous work [16] had illustrated the biological impact of the TCF7L2 in type 2 diabetes and the study suggested that this risk variant was due to the ancestral T allele of an SNP, rs7903146, through replication in West African and Danish with type 2 diabetes case-control studies and another Icelandic study. Then, other authors [17] had evaluated about 43 SNPs and the previously identified DG10S478 microsatellite in African American and suggested again that rs7903146 was the trait-defining polymorphism linked to the development of type 2 diabetes. These previous studies interpret the intron 3 SNP rs7903146 as the causal variant in the TCF7L2 gene. However, the underlying mechanism of it is still elusive [15].

Because the mutations in risk-related variants were present in an intronic region, rather an exon, it was reasonable to suggest that this regulatory process was associated with conferring the risk of T2DM [18]. The previous researchers found that the locus conferred its T2DM risk by transcriptional protein complex binding across rs7903146 within TCF7L2 in a self-regulating manner [18], [19] and provided that the intronic TCF7L2 variants might regulate alternative transcript isoforms, which, in turn, might have a distinct physiologic process in inducing T2DM. One of them may be Acyl-CoA synthetase 5 (ACSL5) which has an important role in both the fatty acid degradation and lipid biosynthesis and which, in turn, might correlate with the insulin resistance [15]. Many previous researches found better maintenance regard to glucose levels [20], [21] and also, improvement in insulin sensitivity [19] in the whole body of the ACSL5 knockout mice. A previous study found that a causal variant within TCF7L2 resides in an element that controls the expression of ACSL5 and suggests that TCF7L2 regulates ACSL5 expression [22].

\section{Effector of Wnt signaling pathway}

TCF7L2 exerts its regulatory effect on the Wnt signaling pathway. This pathway may play a key role in both islet cell proliferation and differentiation [15]. In humans, it had been suggested that T2DM may have a link to a mutation in the TCF7L2 gene associated with the Wnt pathway [23]. TCF7L2 affects proglucagon gene transcription in the endocrine L-cell lines of the gut by mean of the signaling of the Wnt pathway. The proglucagon gene is important as it encodes the incretin hormone glucagon-like peptide-1 [24]. GLP-1 affects glucose by stimulating insulin secretion, inhibiting glucagon secretion, and slowing gastric emptying [25]. Furthermore, GLP-1 provides other effects such as promoting the transcription of the insulin gene, inhibiting $\beta$-cell apoptosis, promoting $\beta$-cell neogenesis, and also promoting its proliferation [26].

Because there was a previous work suggesting that the $\beta$-catenin has a pivotal effect in regard to modulating the secretion of insulin, it was exerted that the overexpression of TCF7L2, as one of the transcriptional coactivator of $\beta$-catenin, will attenuate the secretion of insulin [27].

\section{Proinsulin conversion and $\beta$-cell responsivity}

$\beta$-cells are involved in the production of proinsulin. If proinsulin levels relative to the level of the mature insulin hormone are increased, this might suggested impending insulin resistance and the progression to T2DM [28]. TCF7L2-induced $\beta$-cell apoptosis might occur through obstructing with the proinsulin processing. Moreover, it has been confirmed that the impairment of insulin vesicle trafficking could be done by silencing TCF7L2 [29]. The T-allele of the TCF7L2 rs7903146 was an important risk factor for impaired proinsulin conversion, as has been found by a previous meta-analysis [30].

\section{Conclusion}

We concluded that these polymorphisms had a role in the progression of prediabetes to type $2 \mathrm{DM}$, particularly TNF by affecting insulin resistance and TCF7L2 by affecting mainly insulin secretion. Also, we concluded that type $2 \mathrm{DM}$ can be prevented or at least 
delayed by managing prediabetes by regular exercises and keeping ideal body weight.

\section{References}

1. $\mathrm{Xu} \mathrm{H}$, Uysal $\mathrm{KT}$, Becherer JD, Arner $\mathrm{P}$, Hotamisligil GS. Altered tumor necrosis factor-alpha (TNF-alpha) processing in adipocytes and increased expression of transmembrane TNFalpha in obesity. Diabetes. 2002;51(6):1876-83. https://doi. org/10.2337/diabetes.51.6.1876

PMid:12031976

2. Kabayama K, Sato T, Kitamura F, Uemura S, Kang BW, Igarashi $\mathrm{Y}$, et al. TNF $\alpha$-induced insulin resistance in adipocytes as a membrane microdomain disorder: Involvement of ganglioside GM3. Glycobiology. 2005;15(1):21-9. https://doi. org/10.1093/glycob/cwh135

3. Solomon S, Odunusi O, Carrigan D, Majumdar G, Kakoola D, Lenchik N, et al. TNF- $\alpha$ inhibits insulin action in liver and adipose tissue: A model of metabolic syndrome. Horm Metab Res. 2010;42(2):115-21. https://doi.org/10.1055/s-0029-1241834

4. da Rocha AF, Liboni TF, Kurauti MA, de Souza CO, Miksza DR, Moreira CC, et al. Tumor necrosis factor alpha abolished the suppressive effect of insulin on hepatic glucose production and glycogenolysis stimulated by cAMP. Pharmacol Rep. 2014;66:380-5. https://doi.org/10.1016/j.pharep.2013.12.005 PMid:24905512

5. Shoelson SE, Lee J, Goldfine AB. Inflammation and insulin resistance. J Clin Invest. 2006;116(7):1793-801.

PMid:16823477

6. Ruan H, Lodish HF. Insulin resistance in adipose tissue: Direct and indirect effects of tumor necrosis factor-alpha. Cytokine Growth Factor Rev. 2003;14(5):447-55. https://doi.org/10.1016/ s1359-6101(03)00052-2

PMid: 12948526

7. Cawthorn WP, Sethi JK. TNF-alpha and adipocyte biology. FEBS Lett. 2008;582(1):117-31.

PMid: 18037376

8. Kern PA, Ranganathan S, Li C, Wood L, Ranganathan G. Adipose tissue tumor necrosis factor and interleukin-6 expression in human obesity and insulin resistance. Am J Physiol Endocrinol Metab. 2001;280(5):E745-51. https://doi. org/10.1152/ajpendo.2001.280.5.e745

PMid: 11287357

9. Plomgaard P, Bouzakri K, Krogh-Madsen R, Mittendorfer B, Zierath JR, Pedersen BK. Tumor necrosis factor-alpha induces skeletal muscle insulin resistance in healthy human subjects via inhibition of Akt substrate 160 phosphorylation. Diabetes. 2005;54(10):2939-45. https://doi.org/10.2337/ diabetes.54.10.2939

PMid:16186396

10. Akash MS, Shen Q, Rehman K, Chen S. Interleukin-1 receptor antagonist: A new therapy for type 2 diabetes mellitus. J Pharm Sci. 2012;101(5):1647-58. https://doi.org/10.1002/jps.23057 PMid:22271340

11. Akash MS, Rehman K, Chen S. Role of inflammatory mechanisms in pathogenesis of type 2 diabetes mellitus. $J$ Cell Biochem. 2013;114(3):525-31. https://doi.org/10.1002/ jcb.24402 PMid:22991242

12. Rehman K, Akash MS. Mechanisms of inflammatory responses and development of insulin resistance: How are they interlinked? J Biomed Sci. 2016;23(1):87. https://doi.org/10.1186/ s12929-016-0303-y

PMid:27912756

13. Parkash J, Chaudhry MA, Rhoten WB. Tumor necrosis factoralpha-induced changes in insulin-producing $\beta$-cells. Anat Rec A Discov Mol Cell Evol Biol. 2005;286(2):982-93. https://doi. org/10.1002/ar.a.20229

PMid: 16114068

14. Donath MY, Shoelson SE. Type 2 diabetes as an inflammatory disease. Nat Rev Immunol. 2011;11(2):98-107.

PMid:21233852

15. Huang ZQ, Liao YQ, Huang RZ, Chen JP, Sun HL. Possible role of TCF7L2 in the pathogenesis of Type 2 diabetes mellitus. Med Biotechnol Biotechnol Equip. 2018;32(4):830-4.

16. Gunnarsdottir S, Adeyemo A, Chen Y, Chen G, Reynisdottir I, Benediktsson R, et al. Refining the impact of TCF7L2 gene variants on Type 2 diabetes and adaptive evolution. Nat Genet. 2007;39(2):218-25

PMid:17206141

17. Palmer ND, Hester JM, An SS, Adeyemo A, Rotimi C, Langefeld $C D$, et al. Resequencing and analysis of variation in the TCF7L2 gene in African Americans suggests that SNP rs 7903146 is the causal diabetes susceptibility variant. Diabetes. 2011;60(2):662-8. https://doi.org/10.2337/db10-0134 PMid:20980453

18. Xia Q, Deliard S, Yuan CX, Johnson ME, Grant SF Characterization of the transcriptional machinery bound across the widely presumed type 2 diabetes causal variant, rs7903146, within TCF7L2. Eur J Hum Genet. 2014;23(1):103-9. https://doi. org/10.1038/ejhg.2014.48

PMid:24667787

19. Mondal AK, Das SK, Baldini G, Chu WS, Sharma NK, Hackney OG, et al. Genotype and tissue-specific effects on alternative splicing of the transcription factor 7 -like 2 gene in humans. J Clin Endocrinol Metab. 2010;95(3):1450-7. https://doi.org/10.1210/ jc.2009-2064 PMid:20097709

20. Koscielny G, Yaikhom G, Iyer V, Meehan TF, Morgan H, AtienzaHerrero J, et al. The international mouse phenotyping consortium web portal, a unified point of access for knockout mice and related phenotyping data. Nucleic Acids Res. 2014;42:D802-9. https://doi.org/10.1093/nar/gkt977

PMid:24194600

21. Bowman TA, O'Keeffe KR, D'Aquila T, Yan QW, Griffin JD, Killion EA, et al. Acyl CoA synthetase 5 (ACSL5) ablation in mice increases energy expenditure and insulin sensitivity and delays fat absorption. Mol Metab. 2016;5(3):210-20. https://doi. org/10.1016/j.molmet.2016.01.001

PMid:26977393

22. Xia Q, Chesi A, Manduchi E, Johnston BT, Lu S, Leonard ME, et al. The type 2 diabetes presumed causal variant within TCF7L2 resides in an element that controls the expression of ACSL5. Diabetologia. 2016;59(11):2360-8. https://doi. org/10.1007/s00125-016-4077-2 PMid:27539148

23. Maschio DA, Oliveira RB, Santos MR, Carvalho CP, Barbosa-Sampaio HC, Collares-Buzato CB. Activation of the Wnt/ $\beta$-catenin pathway in pancreatic beta cells during the compensatory islet hyperplasia in prediabetic mice. Biochem Biophys Res Commun. 2016;478(4):1534-40. https://doi. org/10.1016/j.bbrc.2016.08.146 PMid:27576200

24. Shao W, Wang D, Chiang YT, Ip W, Zhu L, Xu F, et al. The Wnt signaling pathway effector TCF7L2 controls gut and brain proglucagon gene expression and glucose homeostasis. 
Diabetes. 2013;62(3):789-800. https://doi.org/10.2337/db12-0365 PMid:22966074

25. Nadkarni P, Chepurny OG, Holz GG. Regulation of glucose homeostasis by GLP-1. Prog Mol Biol TransI Sci. 2014;121:23-65. PMid:24373234

26. Manandhar B, Ahn JM. Glucagon-like Peptide-1 (GLP-1) analogs: Recent advances, new possibilities, and therapeutic implications. J Med Chem. 2015;58(3):1020-37. https://doi. org/10.1021/jm500810s

PMid:25349901

27. Sorrenson B, Cognard E, Lee KL, Dissanayake WC, Fu Y, Han W, et al. A critical role for $\beta$-catenin in modulating levels of insulin secretion from $\beta$-cells by regulating actin cytoskeleton and insulin vesicle localization. J Biol Chem. 2016;291(50):25888-900. https://doi.org/10.1074/jbc.m116.758516

PMid:27777306
28. Mykkänen L, Haffner SM, Hales CN, Rönnemaa T, Laakso M The relation of proinsulin, insulin, and proinsulin-to-insulin ratio to insulin sensitivity and acute insulin response in normoglycemic subjects. Diabetes. 1997;46(12):1990-5. https:// doi.org/10.2337/diabetes.46.12.1990 PMid:9392485

29. da Silva Xavier G, Loder MK, McDonald A, Tarasov Al, Carzaniga R, Kronenberger K, et al. TCF7L2 regulates late events in insulin secretion from pancreatic islet beta-cells. Diabetes. 2009;58(4):894-905. https://doi.org/10.2337/db08-1187 PMid:19168596

30. Shen J, Fang $\mathrm{Y}, \mathrm{Ge} \mathrm{W}$. Polymorphism in the transcription factor 7-like 2 (TCF7L2) gene is associated with impaired proinsulin conversion-a meta-analysis. Diabetes Res Clin Pract. 2015;109(1):117-23. https://doi.org/10.1016/j. diabres.2015.04.020

PMid:25934528 